\title{
11: 111540050-111519186
}

National Cancer Institute

\section{Source}

National Cancer Institute. 11: 111540050-111519186. NCI Thesaurus. Code C44994.

Physical location of IL18_Gene 